\title{
Aktivitas Sitotoksik Ekstrak Etanol Kulit Buah Pinang (Areca catechu) dan Daun Kayu Manis (Cinnamomum burmanni)
}

\section{Cytotoxic Activity of Pinang Fruit Leather (Areca Catechu) and Cinnamon Leaf Ethanol Extract}

\author{
Herdwiani $\mathrm{W}^{1}$, Soemardji $\mathrm{AA}^{2}$, Elfahmi ${ }^{2}$, Tan $\mathrm{MI}^{3}$ Nabila $\mathrm{K}^{1}$, Anita $\mathrm{K}$ \\ ${ }^{1}$ Fakultas Farmasi, Universitas Setia Budi, Surakarta, Indonesia, ${ }^{2}$ Sekolah Farmasi Institut Teknologi Bandung, ${ }^{3}$ SITH \\ Institut Teknologi Bandung, herdwiani@gmail.com ${ }^{1}$
}

\begin{abstract}
ABSTRAK
Tanaman pinang (Areca cathecu) dan kayu manis (Cinnamomum burmannii) adalah tanaman tradisional yang diduga memiliki khasiat sebagai antikanker. Penelitian ini dimaksudkan untuk mengetahui efek sitotoksik dari ekstrak etanol kulit buah pinang (Areca catechu) terhadap kultur sel kanker payudara T47D \& ekstrak etanol daun kayu manis (Cinnamomum burmannii) terhadap kultur sel kanker kolon WiDr

Simplisia yang diperoleh selanjutnya dimaserasi untuk memperoleh ekstrak etanol kulit buah pinang dan daun kayu manis. Metode yang digunakan dalam pengujian aktifitas sitotoksik adalah MTT (3-[4,5-dimetilthiazol-2yl]-2, 5-difeniltetrazolium bromide) untuk mendapatkan nilai $\mathrm{IC}_{50}$.

Hasil penelitian menunjukkan bahwa ekstrak kulit buah pinang tidak memiliki efek sitotoksik terhadap kultur T47D dan memiliki nilai IC $\mathrm{C}_{50} 467,34 \mu \mathrm{g} / \mathrm{mL}$. Ekstrak daun kulit kayu manis tidak memiliki efek sitotoksik terhadap kultur WiDr dan memiliki nilai IC ${ }_{50} 405,69 \mu \mathrm{g} / \mathrm{ml}$.
\end{abstract}

Kata kunci : Kayu manis, pinang, sitotoksik, T47D, WiDr.

\section{ABSTRACT}

The areca plant (Areca cathecu) and cinnamon (Cinnamomum burmannii) have anticancer properties. The aim of this research is to know the cytotoxic effect of Areca catechu of ethanol extract on T47D breast cancer cell culture and Cinnamomum burmannii leaves of ethanol extract on WiDr colon cancer cell culture.

The obtained simplicia macerated to obtain ethanol extract of pinang peel and cinnamon leaves. The method used in testing cytotoxic activity was MTT (3- [4,5-dimethylthiazol-2yl] -2, 5diphenyltetrazolium bromide) to obtain $\mathrm{IC}_{50}$ values.

The results showed that ethanol extract of pinang peel and cinnamon leaf did not have cytotoxic effect on T47D culture with IC $\mathrm{C}_{50} 467,34 \mu \mathrm{g} / \mathrm{mL}$ and on WiDr culture with IC 50 405,69 $\mu \mathrm{g} / \mathrm{ml}$.

Key word : Areca cathecu, Cinnamomum burmannii, cytotoxic, T47D, WiDr

\section{PENDAHULUAN}

Kanker adalah suatu penyakit yang ditandai dengan adanya pertumbuhan sel-sel jaringan tubuh yang tidak normal. Sel-sel kanker akan berkembang dengan cepat, tidak terkendali, dan akan terus membelah diri, selanjutnya menyusup ke jaringan sekitarnya dan terus menyebar (metastase) (Katzung, 2002). Kanker merupakan penyebab kematian terbesar kedua setelah penyakit kardiovaskular (Sukardiman et al. 2004). Kanker payudara merupakan salah satu jenis kanker yang banyak diderita oleh kaum wanita. Jumlah kasus kanker payudara pada tahun 2014 pada wanita sebanyak 48.998 kasus di Indonesia (WHO, 2014). Perkembangan penyakit kanker kolon di Indonesia semakin meningkat tiap tahunnya, dan insidensinya adalah nomor ketiga 
setelah kanker paru dan kanker payudara (Riskesdas, 2013).

Penelitian khususnya terhadap pengembangan dan penemuan antikanker yang aman dan efektif mutlak diperlukan. Usaha menemukan antikanker yang lebih spesifik dan sensitif dapat dilakukan melalui pemanfaatan tanaman obat yang diduga berkhasiat sebagai antikanker. Tanaman tradisional yang diduga memiliki khasiat sebagai antikanker adalah tanaman pinang (Areca cathecu) dan kayu manis (Cinnamomum burmannii).

Pinang mengandung alkaloid, flavonoid, terpenoid, fenolik, dan tanin (IARC, 2004). Aktivitas sitotoksik secara in vitro terhadap sel leukemia L1210 dari ekstrak etanol biji pinang diperoleh nilai $\mathrm{IC}_{50} 24,73 \mu \mathrm{g} / \mathrm{mL}$ (A'yun, 2016). Aktifitas sitotoksik ekstrak biji pinang diduga salah satunya disebabkan oleh flavonoid yang mampu menghambat proliferasi pada berbagai sel kanker pada manusia, namun tidak toksik terhadap sel normal manusia (Ren et al. 2003).

Kandungan senyawa aktif dari tanaman kulit kayu manis adalah minyak atsiri, safrole, sinamaldehid, eugenol, tanin, damar, kalsium oksalat, flavonoid, saponin serta kandungan gizi lainnya seperti gula, protein, lemak kasar dan pektin. Sinamaldehid mampu menghambat proliferasi, invasi, dan pertumbuhan tumor. Sinamaldehid yang diisolasi dari $C$. cassia juga telah terbukti memiliki efek antiangiogenesis atau pengahmabt pertumbuhan pembuluh darah baru dan dapat disimpulkan bahwa sinamaldehid dan derivatnya memiliki aktivitas antitumor (Kwon et al. 1998). Berdasarkan penelitian dari Lean-Teik $\mathrm{Ng}$ dan ShuJing Wu (2009) potensi antiproliferatif sinamaldehid dengan $\mathrm{IC}_{50} 9,76 \pm 0,67 \mathrm{M}$ sebaik dengan obat antikanker 5fluorouracil dengan $\mathrm{IC}_{50} 9,57 \pm 0,61 \mathrm{M}$.
Anjarsari (2013) melaporkan bahwa destilat kayu manis mempunyai efek sitotoksik pada sel T47D dengan nilai $\mathrm{IC}_{50}$ sebesar $75 \mu \mathrm{g} / \mathrm{ml}$. Minyak atsiri kulit kayu manis memiliki nilai ${ } C_{50}$ terhadap kultur sel WiDr. Ekstrak etanol kayu manis mempunyai efek imunostimulator yang ditandai dari kenaikan jumlah sel $\mathrm{T}$ CD4 dan T CD8 (Hasan et al. 2013 ).

Penelitan ini dimaksudkan untuk mengetahui efek sitotoksik ekstrak etanol kulit buah pinang (Areca catechu) terhadap kultur sel kanker payudara T47D \& ekstrak etanol daun Kayu Manis (Cinnamomum burmannii) terhadap kultur sel kanker kolon WiDr.

\section{METODE PENELITIAN}

\section{Alat dan Bahan}

Alat ekstraksi maserasi, alat identifikasi senyawa aktif, alat SterlingBidwell, sentrifuge Sigma 3K12 (B. Braun Biotech International), Laminar Air Flow class II (Labconco), ELISA reader (SLT 240 ATC), Nebauer Haemocytometer (Olympus CKX41), mikroplate 96 sumuran (Nunclone), mikroskop inverted, magnetic stirrer dan kamera digital dan alat-alat gelas lazim.

Reagen uji sitotoksik MTT (Axiovert-25), serbuk kulit buah pinang dan kayu manis, etanol p.a, etanol 96\%, reagen identifikasi senyawa aktif, kultur sel T47D, kultur sel WiDr, media RPMl 1640 (Gibco), Fetal Bovine Serum (FBS) $10 \%$, v/v (Gibco), larutan PBS (Phosphat Buffered Saline) pH 7,2 ; Natrium Dodesil Sulfat $10 \%$ dalam $\mathrm{HCl}$ $0,1 \mathrm{~N}$ sebagai stopper, penisillinstreptomisin 1\% v/v (Gibco).

\section{METODE PENELITIAN}

\section{Pembuatan serbuk kulit buah} pinang \& daun kayu manis

Simplisia yang diperoleh kemudian diserbuk dan diayak dengan ayakan No.40 untuk memperoleh serbuk 
simplisia. Serbuk dilakukan penetapan kadar air.

\section{Pembuatan ekstrak}

Ekstrak etanol kulit buah pinang dan ekstrak etanol daun kayu manis diperoleh dengan metode maserasi. Sebanyak 250 gram serbuk dimasukkan dalam botol cokelat ditambah etanol 96\% $1875 \mathrm{~mL}$. Maserasi dilakukan kurang lebih selama 5 hari dengan penggojogan. Setelah 5 hari ditambahkan pelarut etanol $96 \%$ secukupnya sampai diperoleh sari sebanyak $2500 \mathrm{ml}$. Kemudian disaring dengan kain flannel. Maserat yang didapat dipekatkan dengan rotary evaporator (suhu tetap dijaga pada $40^{\circ} \mathrm{C}-50^{\circ} \mathrm{C}$ ) sampai diperoleh ekstrak kental.

\section{Standarisasi ekstrak}

Identifikasi kandungan senyawa kimia ekstrak etanol kulit buah pinang dan daun kayu manis dilakukan secara kualitatif dengan uji reagen dan uji penegasan dengan KLT (Kromatografi Lapis Tipis).

\section{Uji aktivitas sitotoksik}

Metode yang digunakan dalam pengujian aktifitas sitotoksik adalah metode MTT (3-[4,5-dimetilthiazol-2yl]2, 5-difeniltetrazolium bromide). Larutan uji sebanyak $100 \mu \mathrm{L}$ disuspensikan dengan $100 \mu \mathrm{L}$ sel dalam medium RPMI 1640 (Foetal Bovine Serum (FBS) $10 \% \mathrm{v} / \mathrm{v}$ penisillinstreptomisin $1 \% \mathrm{v} / \mathrm{v}$ ) (kepadatan $2 \times 10^{4}$ sel/sumuran) kemudian dimasukkan ke dalam microplate 96. Sel diinkubasi selama 24 jam dalam inkubator $\mathrm{CO}_{2} 5 \%$ dengan kelembapan yang sesuai. Sampel dimasukan dalam plate dengan variasi kadar $500 \mu \mathrm{g} / \mathrm{ml} ; 250 \mu \mathrm{g} / \mathrm{ml} ; 125$ $\mu \mathrm{g} / \mathrm{ml} ; 62,5 \mu \mathrm{g} / \mathrm{ml} ; 31,25 \mu \mathrm{g} / \mathrm{ml}$; 15,6 $\mu \mathrm{g} / \mathrm{ml} ; 7,8 \mu \mathrm{g} / \mathrm{ml}$. Selanjutnya sampel diinkubasi dalam inkubator $\mathrm{CO}_{2} 5 \%$ selama 24 jam. Sel yang hidup akan bereaksi dengan reagen MTT membentuk warna ungu (formazan).
Media sel selanjutnya dibuang, ditambahkan $110 \mu \mathrm{L}$ reagen MTT ke setiap sumuran, termasuk kontrol media (tanpa sel). Setelah diinkubasi 4 jam, ditambahkan $100 \mu \mathrm{L}$ SDS (Sodium Dodecyl Sulfate) $10 \%$ untuk menghentikan reaksi antara sel hidup dan diinkubasi over night (24 jam) pada suhu kamar di tempat gelap. Pada akhir inkubasi serapan dibaca dengan ELISA reader pada panjang gelombang 570 $\mathrm{nm}$.

masing Data absorbansi masingdikonversikan dalam persen viabilitas sel dengan menggunakan persamaan : $\%$ viabilitas $=(a-b) /(c-b) \times 100 \%$. Keterangan : $a=a b s o r b a n s i ~ s e l$ perlakuan; $b=a b s o r b a s i$ kontrol media; $\mathrm{c}=$ absorbansi kontrol sel

Nilai IC $_{50}$ (Inhibitor Concentration 50), dihitung dengan menggunakan persamaan regresi linear yang menggambarkan hubungan antara persen (\%) viabilitas sel T47D dengan log konsentrasi sampel uji (Setyawan 2006). $Y=b x+a$ Keterangan $: x=\log$ konsentrasi senyawa; $y=$ persen viabilitas sel dan $\mathrm{IC}_{50}=$ anti $\log \mathrm{x}$

\section{HASIL DAN PEMBAHASAN}

\section{Serbuk kulit buah pinang \& daun kayu manis}

Kulit buah pinang yang digunakan dalam penelitian ini diperoleh dari Desa Topobali Kabupaten Flores Timur-NTT dan daun kayu manis yang yang diperoleh dari desa Jambu, Ambarawa, Kabupaten Semarang, Jawa Tengah. Hasil determinasi tanaman menunjukkan bahwa tanaman yang digunakan dalam penelitian ini adalah tanaman pinang (Areca catechu) dan tanaman kayu manis (Cinnamomum burmanni). Kadar air serbuk kulit buah pinang diperoleh sebesar $8,9 \%$ dan serbuk daun kayu manis adalah sebesar $7,5 \%$. 


\section{Ekstrak simplisia}

Ekstrak etanol kulit buah pinang menghasilkan rendemen 6,35\%.

Ekstrak etanol daun kayu manis menghasilkan rendemen $7,99 \%$.

\section{Standarisasi ekstrak}

Hasil identifikasi kandungan senyawa kimia ekstrak etanol kulit buah pinang dan kulit kayu manis secara kualitatif dapat dilihat pada tabel 1 .

Tabel 1. Hasil identifikasi senyawa kimia dengan uji warna ekstrak kulit buah pinang dan daun kayu manis.

\begin{tabular}{ll}
\hline Golongan senyawa & Hasil \\
\hline Alkaloid & + \\
Saponin & + \\
Flavonoid & + \\
Tanin & + \\
Triterpen & + \\
\hline
\end{tabular}

Pemeriksaan KLT ekstrak kulit buah pinang dapat dilihat pada gambar 1 .

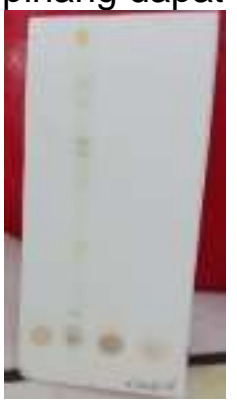

a

Gambar 1. a) sebelum penyemprotan, b) deteksi pada sinar UV 254 nm, c) deteksi pada sinar UV 366 $\mathrm{nm}$.

Pemeriksaan KLT terhadap senyawa sinamaldehid dan flavonoid yang diketahui memiliki aktivitas antioksidan dan antiproliferatif (Kuo et al. 2005). Diperoleh hasil seperti pada gambar 2.
a. sinamaldehid

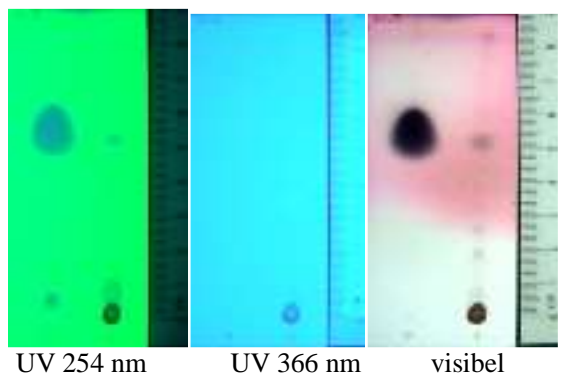

Gambar 2. Profil KLT sinamaldehide dan ekstrak etanol daun kayu manis (E) dengan fase diam Silicagel $60 \mathrm{~F}_{254}$, fase gerak butanol - asam asetat air (3:1:1) dan disemprot dengan aluminium chlorida serta dideteksi sinar UV a) $254 \mathrm{~nm}$, b) 365 , c) visibel.

\section{a. Flavonoid}

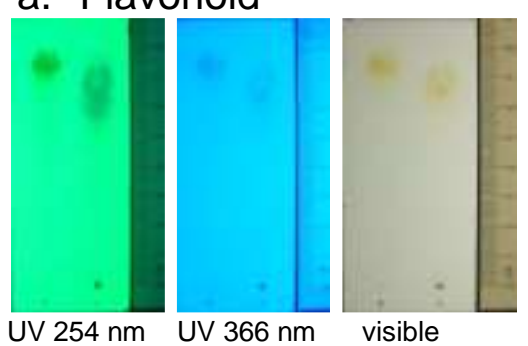

Gambar 3. Profil KLT flavonoid rutin (R) dan ekstrak etanol kulit kayu manis (E) dengan fase diam Silicagel $60 F_{254}$, fase gerak butanol - asam asetat air (3:1:1) dan disemprot dengan aluminium chlorida serta dideteksi sinar UV a) $254 \mathrm{~nm}$, b) 365, c) visibel.

4. Hasil uji sitotoksik. Persamaan ekstrak etanol kulit buah pinang adalah $y=-75.381 x+251.24, \quad(r=0.934)$. Berdasarkan persamaan linear ini didapatkan nilai $\mathrm{IC}_{50}$ dari ekstrak etanol kulit buah pinang sebesar 467, 34 $\mu \mathrm{g} / \mathrm{mL}$. Berdasarkan kajian pustaka yang dilakukan oleh Mamonto et al. (2014), kulit buah pinang mengandung senyawa flavonoid yang juga dibuktikan melalui uji kualitatif menggunkan metode tabung. Sebagian besar senyawa flavonoid diduga mampu menghambat proliferasi pada berbagai sel kanker manusia (Ren et al. 2003). Senyawa flavonoid merupakan metabolit sekunder yang terkandung pada pinang yang memiliki khasiat antikanker mempunyai sifat kepolaritasan yang bersifat semipolar. 
Kepolaritasan ini diharapkan dapat menembus sel kanker yang bersifat non-polar sehingga dapat memberikan efek terhadap penghambatan sel kanker.

Hasil aktifitas sitotoksik ekstrak kulit buah pinang dapat dilihat pada gambar 4

a

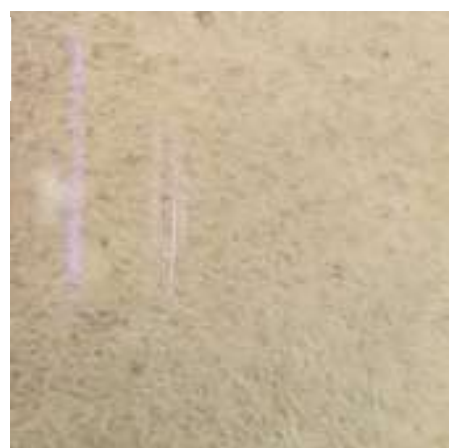

b

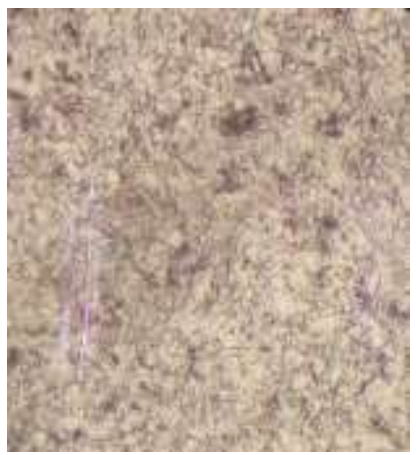

Gambar 4. Morfologi sel kanker payudara T47D setelah pemberian ekstrak etanol kulit buah pinang (a) konsentrasi 1000 $\mu \mathrm{g} / \mathrm{mL}$; (b) konsentrasi 15,63 $\mu \mathrm{g} / \mathrm{mL}$

Hasil aktifitas sitotoksik ekstrak daun kayu manis dapat dilihat pada gambar 5

a)
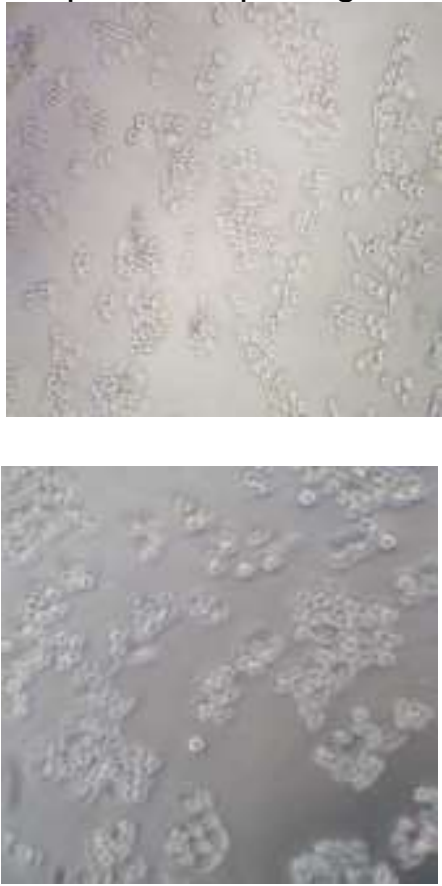

Gambar 4. Morfologi sel WiDr dari ekstrak etanol daun kayu manis sebelum diberi MTT, a) konsentrasi $500 \mu \mathrm{g} / \mathrm{ml}$; b) konsentrasi $31,25 \mu \mathrm{g} / \mathrm{ml}$

Persamaan regresi linear yang diperoleh dari ekstrak etanol daun kayu manis yaitu $y=-43,67 x+163,9$ dan nilai $r=0,983$. Nilai $I_{50}$ dihitung dengan memasukan nilai y sebesar 50\% sehingga diperoleh nilai antilog $\mathrm{x}$ sebagai $\mathrm{IC}_{50}$ yaitu $405,69 \mu \mathrm{g} / \mathrm{ml}$.

Kematian sel tersebut disebabkan adanya senyawa yang mampu memicu apoptosis sel. Ekstrak etanol kulit kayu manis mengandung beberapa metabolit sekunder yang bersifat antikanker, diantaranya sinamaldehid dan flavonoid. Jenis sinamaldehid yang terkandung dalam kayu manis adalah trans-cinnamaldehyde, alpha-amyl cinnamaldehyde dan trans-cinnamic alcohol (Elahi et al. 2004). Sedangkan golongan flavonoid yang terkandung dalam kayu manis adalah quarsetin, kaempferol, luteolin, rutin dan pelargonidin (Jayaprakasha et al. 2000).

Penelitian

terdahulu menyatakan bahwa kandungan sinamaldehid yang merupakan senyawa aktif dalam minyak kayu manis mampu menginduksi apoptosis melalui induksi apoptosis mitochondrial permeability transition (MPT) (Ka et al. 2003). Peningkatan permeabilitas membran mitokondria akan meyebabkan pengeluaran sitokrom c yang mengaktivasi caspase 3 dan dapat menyebabkan terjadinya apoptosis (Mitzutani et al. 2005). Hal ini sesuai dengan penelitian terdahulu bahwa kandungan sinamaldehid dari minyak 
atsiri kulit kayu manis mempunyai efek sitotoksik terhadap sel kanker kolon WiDr yaitu $I_{50}$ sebesar $13,70 \mu \mathrm{g} / \mathrm{ml}$ (Herdwiani, 2014). Kandungan flavonoid juga telah terbukti mampu menghambat proliferasi pada berbagai sel kanker pada manusia. Flavonoid menghambat ekspresi enzim topoisomerase I dan topoisomerase II yang berperan pembentukan DNA (Ren et al. 2003). Namun rendahnya aktivitas sitotoksik ekstrak etanol dan $n$-heksana daun kayu manis terhadap sel WiDr ini kemungkinan disebabkan oleh rendahnya kadar sinamaldehid dan flavonoid pada daun kayu manis yang berefek sitotoksik.

Flavonoid merupakan agen kemopreventif dengan menghambat protein COX-2, selain itu flavonoid juga menghambat protein COX-2 independen lainnya seperti Akt dan NFkB. Akt mempunyai peranan penting dalam regulasi pertahanan siklus sel dan proliferasi sel kanker dengan mempengaruhi status phosporilasi berlebihan baik dari Akt. Sehingga blokade signal tersebut menyebabkan hambatan pertumbuhan dengan penghentian siklus sel dan apoptosis dari sel kanker. NF-kB adalah faktor transkripsi yang terlibat dalam fungsi seluler yang luas, di antaranya apoptosis dan kontrol siklus sel. Penelitian yang dilakukan oleh Pan et al.(2002), menjelaskan bahwa flavonoid dapat menginduksi penghentian fase G1 pada siklus sel. Aktivitas antikanker juga ditunjukkan flavonoid melalui induksi apoptosis. Flavonoid menghambat ekspresi enzim topoisomerase I dan topoisomerase II. Inhibitor enzim topoisomerase akan menstabilkan kompleks topoisomerase dan menyebabkan DNA terpotong dan mengalami kerusakan. Kerusakan DNA dapat menyebabkan terekspresinya protein proapoptosis seperti Bax dan Bak dan menurunkan ekspresi protein- protein antiapoptosis yaitu $\mathrm{Bcl}-2$ dan Bcl-XI, yang menyebabkan pertumbuhan sel kanker terhambat (Pan et al., 2002). Flavonoid telah terbukti mampu menghambat proliferasi pada berbagai sel kanker pada manusia namun bersifat tidak toksik pada sel normal manusia (Ren et al. 2003).

Ekstrak kayu manis berpotensi menghambat berbagai pertumbuhan sel tumor secara in vivo dan mampu menekan perkembangan sel melanoma secara in vivo. Efek antikanker dari ekstrak kayu manis dimediasi oleh induksi apoptosis dan blokade NF-kB dan AP1 dan gen targetnya adalah Bcl2 dan Bcl-xL (Kwon et al. 2010). Berdasarkan penelitian Lean-Teik $\mathrm{Ng}$ dan Shu-Jing Wu, Sinamaldehid yang terkandung dalam kayu manis memiliki aktivitas antiproliferatif paling kuat pada sel Hep G2 dan sinamaldehid juga dapat menginduksi sinyal apoptosis. Aktivitas Cinnamomum cortex diketahui berdasarkan pada stimulasi sistem reticuloendothelial (RES) dan telah terbukti terkait erat dengan produksi TNF (Tumor necrosis factor) (Haranaka et al. 1985). Cinnamaldehyde mampu menginduksi apoptosis sel melalui reactive oxygen species (ROS), sehingga menginduksi mitochondrial permeability transition (MPT) dan sitokrom C lepas dalam sitosol (Ka et al. 2003).

\section{KESIMPULAN}

Ekstrak kulit buah pinang tidak memiliki efek sitotoksik terhadap kultur sel T47D dan memiliki nilai $I_{50}=467,34 \mu \mathrm{g} / \mathrm{mL}$. Ekstrak daun kulit kayu manis tidak memiliki efek sitotoksik terhadap kultur sel WiDr dan memiliki nilai $\mathrm{IC}_{50}=405,69$ $\mu \mathrm{g} / \mathrm{ml}$.

\section{UCAPAN TERIMAKASIH}

Kemenristek Dikti atas Hibah Penelitian Dosen Pemula. 
DAFTAR PUSTAKA

A'yun, 2016, Aktivitas sitotoksik ekstrak etanol biji pinang (Areca catechu) terhadap sel leukemia L1210, Skripsi, Universitas Setia Budi

Anjarsari, E,Y.,(2013): Potensi destilat kayu manis (Cinnamomum burmanni) sebagai agen ko=kemoterapi Doxorubicin melalui induksi apoptosis pada sel kanker payudara T47D, Skrispsi, Yogyakarta, Fakultas Farmasi Universitas Gadjah Mada

Depkes, 1985, Sediaan Galenika, Jakarta, Departemen Kesehatan Republik Indonesia.

Elahi EN et al. 2004. Protein binding and metabolism influence the relative skin sensitization potential of cinnamic compounds. Chem Res Toxicol 17:301-310.

Haranaka et al. 1985. Antitumor activities and tumor necrosis factor producibility of traditional chinese medicines and crude drugs. Cancer Immunol Immunother 20:1-5.

Hasan FA, Sri M, Rositawati I. 2013. Efek imunostimulator ekstrak etanol kayu manis (Cinnamomum burmanii) terhadap peningkatan jumlah sel T CD4 dan T CD8 pada mencit balb/c. Program studi Kedokteran Hewan Universitas Brawijaya.

Herdwiani W., Fransiska L, Sari R, Yolanda, Rica, Zahra, Ikawati Z, Hertiani T., (2014): Uji keamanan dan uji aktifitas sitotoksik minyak kayu manis (Cinnamomum burmannii) untuk menghasilkan fitofarmaka antikanker, Indonesian Journal of Pharmaceutical Science and Technology, 1, 2014

IARC, 2004, Tobacco smoke and involuntary smoking, IARC
Monogr Eval Carcinog Risk Hum; 83:1-1438

Jayaprakasha GK, Jagan M, Rao L, Sakariah KK. 2000. Chemical composition of the flower oil of Cinnamomum zaylanicum Blume. J Agric Food Chem 48:4294-4295.

$\mathrm{Ka} \mathrm{H}$ et al. 2003. Cinnamaldehyde induces apoptosis by ROSmediated mitochondrial permeability transition in human promyelocytic leukimia HL-60. Cancer Lett 196:143-152.

Katzung, B.G. 2002. Farmakologi Dasar dan Klinik. Buku 2. Bagian Farmakologi Fakultas Kedokteran Universitas Airlangga, penerjemah. Jakarta : Salemba Medika. Terjemahan dari : Basic \& Clinical Pharmacology. hlm 449-462.

Kuo YC, Lin YL, Liu CP, 2005, Antimicrobial agent and chemotherapy, J Chin Med Assoc, 68(6):272-5

Kwon, B.M., Lee, S.H., dan Choi, S.U., (1998): "Synthesis and in vitrocytotoxicity of cinnamaldehydes to human solid tumor cells, Archives of Pharmacology Research, 21, 147-152.

Kwon, H.K., Hwang, J.S., So, J.S., Lee, C.G., Anupama, S., Ryu, J.H., Won, K.J., Byoung, S.K., Im, C.R., Lee, S.H., Zee, Y.P., dan Im, S.H., (2010): cinnamon extract induces tumor cell death through inhibition of Nf_kappa B and Ap1, BMC Cancer, 10, 39298.

Lean-Teik Ng dan Shu-Jing Wu. 2009. Antiproliferative activity of Cinnamomum cassia constituents and effects of pifithrin-alpha on their apoptotic signaling pathways in hep G2 cells. Hindawi Publishing 
Corporation Evidence-Based Complementary and Alternative Medicine 2011:1-6.

Mamonto, I.S., Runtuwene,M.R.J dan Wehantow, F., 2014. Aktifitas antioksidan Ekstrak Kulit Biji Buah Pinang Yaki (Areca vestiaria Giseke), Jurnal IImiah Farmasi-UNSTRAT, 3: 263-272.

Pan MH, Chen WJ, Lin S, Ho CH, Lin JK. 2002. Tangeretin induces cell cycle through inhibiting cyclin dependent kinase $2 \& 4$ activities as well as elevating cok inhibitor p21 in human colorectal carcinoma cells. Carcinogenesis. Oxford University Press 23:1677-1684.

Ren W, Qiao Z, Wang H, Zhu L, Zhang L. 2003. Flavonoids: Promising Anticancer Agent. Medical Research Review 23:519-534.

Riskesdas (Riset Kesehatan Dasar), (2013): Badan Penelitian dan Pengembangan Kesehatan, Kementerian Kesehatan RI.

Sukardiman, Sismindari and Noor Cholies Zaini, 2004, Anticancer activity of Pinostrobin and AndrographolideProceeding of Congress of Pharmaceutical Future, Tokyo Japan, October 2005.

WHO, 2014, The Global burden of disease, World Health Organization. 